\title{
LITERASI MEDIA PADA GENERASI MILENIAL DI ERA DIGITAL
}

\author{
Oleh: \\ SAPTA SARI \\ Program Studi Ilmu Komunikasi Fakultas Ilmu-Ilmu Sosial \\ Universitas Dehasen Bengkulu
}

\begin{abstract}
Media literacy in the Millennial generation in the digital era is still not well implemented. We still see and read a lot of information that is still not clear the truth on social media. This research was conducted to see how media literacy in the Millennial generation in the digital era, especially in social media. Research uses a qualitative method with a literature study approach, by analyzing theories and analyzing based on phenomena that occur so that a comprehensive understanding of the application of media literacy in Millennials in the digital age is obtained. The results of the study revealed, first the literacy of the pause in the digital age is still not well implemented in society even though they are already adept at using digital devices. This bias can be seen that there is still a lot of information found that the truth is not yet distributed in social media by Millennials. Second, the Millennial generation is the term for the generation born in the 1980 to 2000 range. Those who are said to be the Millennial generation are the generation who are currently aged 19 to 40 years, or school age to productive / worker age. Third, Millennial generation interaction with social media in the digital era is very intense. This generation is very ska surfing on social media to share information, entertainment, highlight their existence, mingle with the community in chat groups. Fourth, the development of media literacy in the Millennial generation in the digital era is still not as expected. Millennials do not have good knowledge about media literacy, so there are still many violations in social media, especially in terms of filtering and disseminating information to the public.
\end{abstract}

Keywords: media literacy, millennial generation, media literacy in the digital era

\section{PENDAHULUAN}

Generasi milenial beberapa tahun belakangan ini sering didengungkan, terutama di media sosial. Generasi ini merupakan generasi yang sangat dekat dengan dunia digital karena menjadikan digital sebagai ruang pribadinya dalam mengakses, mendapatkan, membagikan semua bentuk informasi yang mereka temui di internet. Apapun yang mereka temui ketika berselancar segera dijadikan sumber informasi untuk dibagikan ke publik. Tidak jarang jika generasi milenial ini disebut sebagai masyarakat digital yang dengan mudahnya memviralkan apapun yang terjadi dijagat maya. Salah satu media yang dijadikan sebagai tempat eksis memviralkan semua informasi di internet adalah media sosial. Sering kali kita mendengar dan melihat maraknya informasi-informasi yang menjadi viral di media sosial yang dibagikan oleh generasi milenial ini, padahal belum tentu apa yang mereka viralkan itu adalah benar.

Generasi milenial disebut juga dengan generasi praktis atau bahasa gaulnya disebut generasi zaman now. Generasi ini lahir pada rentang tahun 1980-2000an, atau dengan kata lain generasi angkatan 80 -an keatas. Generasi ini muncul sebagai 
bias karena terpengaruh kategorisasi demografik masyarakat barat. Melalui internet di era digital saat ini sangatlah mudah bagi dunia untuk terpengaruh apapun yang terjadi di dunia barat. Interaksi dengan media sosial di dunia maya yang dilakukan oleh generasi milenial ini sangatlah beragam, mulai dari bersosialisasi, eksis, narsis, viral, pilihan politik, sampai bisnis. Tetapi sayangnya, generasi milenial ini secara umum kurang mampu memilah informasi dan cenderung mengesampingkan nilai-nilai moral dan etika dalam eksis dan menyebarkan informasi di media sosial. Oleh sebab itu, banyaknya interaksi yang bisa dilakukan oleh generasi milenial ini, perlu adanya batasan, supaya informasi yang dibagikan bisa dipertanggungjawabkan kebenarannya. Jika tidak interaksi di media sosial tersebut bisa dikategorikan sebagai penyebaran informasi atau berita provokatif sampai pada berita palsu atau yang akrab disebut hoax. Sebagai contoh, masih ingat dalam ingatan kita jika pernah terjadi tawuran antar warga dan pengrusakan sebanyak ratusan rumah di Kabupaten Indramayu, Jawa Barat, yang terjadi pada Selasa 10 Januari 2017, ribuan warga Desa Ilir, Desa Parean Girang, dan DesaBulakmenyerangwarga Blok Bojong, DesaCurug. Tawuran terjadi disebabkan dari kecelakaan tunggal yang dialami Wahyu Maulana (15) dan AtoSuwarto (17), warga Desa Ilir, Sabtu (7/1) petang, di Blok Bojong. Ato tidak sadarkan diri lalu dibawa ke RS Bhayangkara Losarang dan meninggal hari itu juga pukul 04.00. Lalu beredar kabar di akun Facebook milik KK yang menyebutkan Ato meninggal akibat dikeroyok warga Desa Curug (Kompas.com, Kamis 12 Januari 2017). Lalu, ada juga berita pembakaran vihara dan kelenteng di Tanjung Balai Sumatera Utara yang terjadi pada bulan Juli 2016 akibat masyarakat yang termakan hasutan media sosial, kemudian pada pertengahan Desember 2016 dua orang tewas dan satu kritis akibat tawuran di Depok Jawa Barat akibat disulut kabar bohong (Tempo 2-8 Januari 2016).

Selama ini yang terjadi di media sosial, arus informasi yang beredar seakan tanpa kendali, asalkan ada akses internet langsung bisa disebarkan, tanpa dilakukan konfirmasi atau minimal pengecekan kembali apakah informasi tersebut memang benar adanya atau mengandung unsur hoax. Sebenarnya arus informasidari media sosial di era digital ini bisa dikendalikan melalui literasi media yang baik dari masyarakat digital khususnya generasi milenial. Informasi di media sosial memang membuat kita seakan lupa untuk melakukan pengecekan kembali, sehingga informasi yang belum tentu benar atas nama eksis bisa berseliweran tanpa batas. Sebenarnya hal itu bisa dikendalikan dengan pemahaman masyarakat generasi milenial akan pentingnya literasi media, karena mayoritas pengguna media sosial ada pada generasi tersebut. Namun, pada kenyataannya memberantas informasi yang mengandung hoax tidaklah mudah. Usaha untuk menampilkan fakta yang sebenarnya, sering kali gagal. Ini terjadi karena pada dasarnya masalah utama tidak terletak pada informasi palsu itu sendiri, melainkan pada apa yang diyakini oleh seseorang.

Apa itu literasi media pada generasi milenial di era digital? Literasi media di era digital merupakan seperangkat kemampuan yang harus dimiliki seseorang dalam menyaring informasi sekaligus menggunakan perangkat digital seperti internet yang melibatkan kemampuan teknis dan kecerdasan kognitif. Dan generasi millenial adalah istilah untuk generasi yang lahir pada era 1980-an sampai dengan 2000 dan akrab dengan perangkat teknologi digital. Kedua hal tersebut saling berkaitan mengingat teknologi digital yang terus berkembang dengan pesat, dan erat dengan kehidupan kita sehari-hari. Maka sebagai pengguna perangkat digital tersebut, generasi milenial pun dituntut untuk melek terhadap dunia digital. Melek dalam arti memahami, 
mengevaluasi dan membuat sesuatu baik sebagai produsen, maupun konsumen. Teknologi internet tidak hanya memudahkan kita dalam mendapatkan informasi terkini, tetapi juga memberikan kesempatan bagi kita untuk bisa berkarya.

Atas dasar pemikiran di atas, maka perlu dilakukan kajian literatur mendalam untuk melihat bagaimana penerapan literasi media pada generasi milenial di era digital saat ini, terutama pada generasi milenial di Indonesia. Penelitian akan mengemukakan studi literatur penerapan literasi media pada generasi milenial di era digital dalam media sosial, sehingga bisa dilihat apakah generasi milenial di Indonesia sudah menerapkan literasi media dengan baik ataukah tidak.

\section{METODE PENELITIAN}

Metode penelitian yang digunakan dalam penelitian ini adalah pendekatan kualitatif-induktif. Pendekatan ini menggunakan metode kualitatif yang berfokus pada kajian pustaka atau library research. Penelitian ini bermaksud untuk mengeksplorasi data melalui buku-buku referensi dan jurnal penelitian dan analisis dilakukan secara bersamaan.

\section{Sumber Data}

Data sangat penting dalam sebuah penelitian. Adapun yang menjadi sumber data dalam penelitian ini adalah sumber referensi dari buku-buku, jurnal, dan penelitian relevan. Berbagai sumber tersebut dipilih karena dianggap berkaitan dengan penelitian mengenai literasi media pada generasi milenial di era digital. Selainitupenelitianini juga memasukkan data dari sumber berita yang ada di beberapa media massa, diantaranya Kompas dan Tempo.

\section{Teknik Pengumpulan Data}

Teknik pengumpulan data yang digunakan dalam penelitian ini terdiri dari dua cara, yaitu:

1. Dokumentasi, yaitu mengumpulkan data dengan menggunakan catatan dan laporan secara tertulis seperti di surat kabar, majalah, dan berita online.

2. Studi Pustaka, dengan mempelajari buku-buku dari para ahli, jurnal-jurnal ilmiah yang berkaitan dengan fokus dan tema penelitian mengenai literasi media pada generasi milenial di era digital.

\section{Teknik Analisis Data}

Pada penelitian ini akan digunakan teknik analisis kualitatif induktif yang dilakukan untuk mengeksplorasi dan menganalisis fokus penelitian. Teknik ini merujuk pada metode analisis yang interaktif dan lebih secara konseptual untuk menemukan, mengidentiikasi, mengelola, dan menganalisis dokumen dan pustaka untuk memahami makna yang sebenarnya. Sesuai dengan sifat dan teknik yang digunakan dalam penelitian ini, maka data yang diperoleh akan dianalisis dengan tahapan sebagai berikut:

1. Reduksi data yang meliputi proses pemilihan, pemusatan perhatian pada penyederhanaan data, pengabstrakan, transormasi data kasar yang muncul dari sumber data.

2. Penyajian data berupa penampilan sekumpulan informasi yang tersusun sehingga memberi kemungkinan untuk menarik kesimpulan.

3. Penarikan kesimpulan atau verifikasi data penelitian.

4. Peneliti juga akan melakukan triangulasi data berupa perbandingan hasil penelitian dengan realitas atau fenomena sebelum menarik suatu kesimpulan.

Analisis data dilakukan dengan menemukan, mengumpulkan, dan mengkomparasikan secara kualitati berbagai temuan-temuan yang didapatkan. Temuan hasil penelitian ini akan dilakukan secara komprehensi serta mengkaitkannya dengan berbagai konsep dan kajian literature atau pustaka yang berkaitan. Hasil penelitian diharapkan dapat menemukan dan melihat perkembangan literasi media pada generasi milenial di era 
digital, khususnya melalui media sosial di Indonesia.

\section{HASIL PENELITIAN DAN PEMBAHASAN \\ Literasi Media Di Era Digital}

Sejarah literasi media sudah berlangsung sejak lama, tepatnya dimulai pada tahun 1964. Sejarah literasi media mulai berjalan ketika UNESCO mengembangkan sebuah model program pendidikan media, dimana program tersebutakan diterapkan di seluruh dunia (Hobbs: 1999 dalam Lutviah; 2010). Sejak saat itulah, dunia mulai menaruh perhatian pada literasi media, salah satunya adalah dengan melakukan literasi media melalui jalur pendidikan formal dan non formal. Di Indonesia sendiri, kegiatan literasi media sudah dikenal sejak tahun 2000-an seiring dengan bermunculannya dampak media massa kepada khalayak. Saat itu media massa menjadi bagian kehidupan yang akrab di kalangan masyarakat umumnya dan remaja khususnya.

Pertumbuhan dan perkembangan masyarakat bisa dipengaruhi dari segi mental tidak hanya secara fisik. Segi mental bisa dilakukan melalui apa yang didapat dan baca dari media massa. Namun,fenomena yang saat ini terjadi di tengah-tengah masyarakat kita, mental masyarakat lebih banyak informasi dari media massa bahkan sering disuguhi informasi yang belum jelas kebenarannya atau bisa kita katakana sebagai "racun informasi".

Hal ini bisa dilihat dari beberapa pemberitaaan terutama di media sosial yang sering muncul menampilkan perilaku kekerasan, pencurian, kasus korupsi, pornografi, provokasi, pelecehan, gaya hidup bahkan berita yang poluler dikatakan sebagai berita palsu atau hoax, yang jelas-jelas tidak bernilai. Tidak saja di media sosial, tayangan media massa yang menarik bagi masyarakat pun kurang karena dianggap tidak mencerminkan budaya mereka. Padahal, idealnya, mental dan pikiran masyarakat dalam keseharian harus disuguhi "makanan bergizi" dalam hal ini adalah informasi.

Dalam konteks ini adalah isi media sosial yang bernilai pendidikan dan kemanusiaan yang diangkat dari budaya sendiri yang penuh nilai-nilai kearifan. Untuk memahami isi pesan media sosial di era serba digital ini maka diperlukan sebuah tameng atau filter yaitu literasi media. Dengan kata lain, literasi media merupakan paying untuk melindungi khalayak dari aliran informasi media sosial. Literasi media dapat dijadikan sebagai kunci bagi terbentuknya masyarakat yang cerdas dan kritis sehingga tidak mudah tergerus arus informasi dari media sosial.

Literasi media baik yang konvensional maupun yang baru mengajak khalayak sebagai khalayak maupun sebagai komunikator untuk memiliki kemampuan membacak etika dihadapkan dengan media. Teknologi media, khususnya media sosial di era digital mampu mengubahcara orang belajar, bermain dan bermasyarakat di dunia nyata. Berhubungan dengan sesuatu yang baru diperlukan keahlian yang baru pula apalagi subyek yang berhadapan adalah remaja atau generasi muda usia produktif.

Melek media atau lebih dikenal literasi media merupakan satu di antara sekian banyak istilah yang sering dikemukakan dalam beragam kesempatan, baik dalam pembicaraan yang tidak formal hingga diskursus-diskursus akademis. Istilah literasi media tersebut diartikan cukup beragam. Definisi literasi media yang ditawarkan oleh New Media Consortium (2005) adalah sebagai berikut: "The set of abilities and skills where aural, visual and digital literacy overlap. These include the ability to understand the power of images and sounds, to recognize and use that power, to manipulate and transform digital media, to distribute them pervasively and to easily adapt them to new form" (Jefkins, 2009).

Dari kutipan di atas dapat dimaknai bahwa media baru merupakan media yang 
sangat akrab dengan generasi muda saat ini. Keakraban dengan media baru seolah menghalangi yang namanya larangan. Dengan menumbuhkan kesadaran untuk bisa melakukan dialog kritis dapat membantu remaja untuk lebih memahami makna dari pengalaman bermedianya (Kusuma R, 2010).

Sedangkan salah satu defines iliterasi media di era digital yang dipakai secara luas adalah definisi dari The National Leadership Conference on Media Literacy yang merumuskan literasi media sebagai "kemampuan untuk mengakses, menganalisis, mengevaluasi, dan memproduksi media untuk tujuan tertentu" (Aufderheide, 1993:v). Definisi tersebut diperkuat oleh Sonia Livingstone dalam tulisan berjudul What is Media Literacy? Mendefinisikan literasi media sebagai kemampuan untuk mengakses, menganalisis, mengevaluasi dan membuat pesan dalam berbagai konteks. (Fitryarini, 2016: 56-57).

Literasi media merupakan kemampuan dasar yang harus dimiliki seseorang termasuk generasi muda ketika terpaan media sosial di era digital sekarang ini begitu kuat dan terkadang sulit untuk dikendalikan. Kemampuan tersebut bukan kemampuan untuk menolak apalagi menggugat media sosial untuk tidak lagi melakukan aktivitasnya sebagai media penyampai informasi. Namun, literasi media adalah kemampuan dasar dalam memahami media dari aspek penggunaannya hingga pesan yang disajikan. Dengan kemampuan tersebut, diharapkan khalayak termasuk generasi muda tidak mengalami apa yang dikatakan Alwi Dahlan yaitu penyakit disorientasi informasi (Fitryarini, 2016 : 58). Disorientasi informasi adalah suatu keadaan yang membuat khalayak media kehilangan kesadarannya dalam menikmati media. Begitu nikmatnya, hingga khalayak tidak tahu harus berbuat apa dan bagaimana seharusnya.

Lebih khusus lagi, khalayak tidak tahu kebutuhan esensinya terhadap informasi yang disajikan media massa (Choirul, 2013). Akibatnya, hari-harinya akan "disuguhi" informasi sajian media sosial yang tidak jelas, apakah informasi yang dibaca itu berguna bagi khalayak tersebut atau informasi tersebut telah sesuai dengan kebutuhannya atau tidak. Kajian literasi media penting untuk terus dilakukan mengingat media baru dalam hal ini media social memiliki efek cukup besar bagi masyarakat. Hal ini disebabkan pesan yang ditampilkan secara audio visual membawa dampak terhadap khalayak maupun pengguna media. Dampak tersebut meliputi dampak kognitif, afektif dan konatif. Beberapa teori membenarkan perspektif tersebut. Salah satu yang mendukung perspektif tersebut adalah teori masyarakat massa (mass society theory) yang diusung oleh Kornhouser (1959), Bromson (1961), Giner (1979) (Dennis Mc Quail: 2011). Dalam teori ini dijelaskan bahwa, rata rata orang merupakan korban media massa (Richard West and Lynn $\mathrm{H}$ Turner 2007). Hasil penelitian dan pengamatan mereka menuding media yang menyebabkan rusaknya moral individu bahkan kelompok dari suatu komunitas. Literasi media sebagai filter atas dampak yang ditimbulkan media kiranya diperlukan remaja yang saat ini dikelilingi oleh media massa.

Isu utama literasi media bagi kelompok pelajar sebenarnya telah dikampanyekan dalam Partneship for 21st Century Skill, yaitu gerakan yang memfokuskan pada pengembangan kecakapan warga global di abad ke- 21 . Gerakan ini merupakan upaya untuk merespon perubahan masyarakat global dan tantangan-tantangan yang menyertainya melalui revitalisasi pendidikan kewarganegaraan dengan menyiapkan para pelajar memiliki kompetisi ekonomi, produktivitas kerja yang kompleks, keamanan global, dan perkembangan media internet yang sangat krusial bagi keberlangsungan demokrasi. Aspek-aspek kecakapan yang dikembangkan diantaranya meliputi civic 
literacy, global citizenship, dan digital citizenship. Pertama, civic literacy difokuskan pada pengetahuan warga negara tentang hak dan kewajiban yang bersifat lokal, nasional, dan global termasuk bagaimana implikasi dari kebijakan-kebijakan pemerintah di sector publik, ketersediaan informasi dan kemudahan mengaksesnya, serta partisipasi warga negara dalam menyelesaikan persoalan kemasyarakatan. Kedua, global citizenship lewat serangkaian penyiapan warga negara memiliki kemampuan berbahasa asing, kemampuan berkomunikasi dan berkolaborasi dalam kaitannya dengan interaksi antar budaya yang berbeda, pengetahuan dasar yang mencukupi terkait aspek kesejarahan, geografi, politik, ekonomi, dan sains serta kapabilitas untuk memahami suatu persoalan dan bertindak dengan pengetahuan secara interdisipliner dan multidisipliner. Aspek ketiga yaitu digital citizenship melalui pemahaman tentang keamanan menggunakan internet, mengetahui cara menemukan, mengatur dan membuat konten digital termasuk literasi media, dan praktek secara teknis, pemahaman tentang cara berperan untuk meningkatkan tanggungjawab dalam interaksi antar budaya (multikultur), serta pemahaman tentang hak dan kewajiban dalam menggunakan media internet. Aspek ketiga tersebut menjadi penting dan lebih mendesak karena media internet merupakan jalan masuk untuk menerapkan civic literacy ke dunia global atau global citizenship.

\section{Generasi Milenial di Era Digital}

Generasi milenial beberapa tahun belakang ini menjadi fenomena yang tidak bisa dihindari. Bagi yang aktif di media social tentu saja sudah akrab dengan istilah generasi milenial. Media social disinyalir yang membesarkan "nama" generasi milenial ini. Barangkali masih membekas dalam ingatan akan istilah era millennium, yaitu era menjelang awal tahun 2000-an atau yang sering kita sebut dengan zaman millennium. Mereka yang tumbuh dalam kurun masa millennium ini disebut dengan generasi milenial. Benarkah demikian? Siapa generasi milenial? Untuk mengetahui siapa saja yang disebut sebagai generasi milenial diperlukan kajian literature dari berbagai sumber. Hal ini dilakukan untuk mengetahui rentang waktu atau masa yang tepat siapa saja yang masuk kedalam generasi milenial.

Sebelum generasi milenial, sudah ada generasi sebelumnya, yang disebut dengan Generasi X. Generasi X ini menurut pendapat para ahli, generasi yang lahir pada rentang tahun 1960-1980. Generasi $X$ ini dikenal dengan cirri khasnya yang cenderung suka menempuh risiko dan pengambil keputusan yang matang. Setelah generasi $X$, generasi berikutnya adalah generasi Baby Boom, yaitu generasi yang lahir pada rentang tahun 1946-1960. Generasi ini lahir setelah masa perang dunia kedua berakhir sehingga perlu penataan ulang kehidupannya. Disebut Generasi Baby Boom karena di era tersebut kelahiran bayi sangat tinggi. Kemudian generasi tertua adalah yang sering disebut sebagai generasi Veteran yang lahir dibawah tahun 1946. Penyebut istilah generasi ini bermacam-macam oleh para peneliti, seperti Traditionalist, Silent Generation, Veteran, dan Matures.

Masih ada lagi generasi setelah dari generasi milenial ini, yaitu generasi yang disebut dengan Generasi Z. Generasi Z ini adalah generasi yang lahir dalam rentang tahun 2001 sampaidengan 2010. Generasi $\mathrm{Z}$ ini merupakan peralihan dari Generasi Y atau generasi milenial pada saat teknologi sedang berkembang pesat. Pola piker Generasi Z cenderung serba instan. Namun sebagai catatan, generasi tersebut belum akan banyak berperan pada bonus demografi Indonesia pada 2020. Terakhir adalah Generasi Alpha yang lahir pada 2010 hingga sekarang. Generasi ini adalah lanjutan dari generasi $\mathrm{Z}$ yang sudah terlahir pada saat teknologi semakin berkembang pesat. Mereka sudah 
mengenal dan sudah berpengalaman dengan dunia digital seperti gadget, smartphone dan kecanggihan teknologi lainnya ketika usia mereka yang masihdini.

Istilah milenial pertama kalinya dikemukakan oleh William Strauss dan Neil dalam bukunya yang berjudul Millennials Rising: The Next Great Generation (2000). Mereka menciptaka nistilah milenial ini pada tahun 1987, yaitu pada saat anak-anak yang lahir pada tahun 1982 masuk pra-sekolah. Saat itu media mulai menyebut sebagai kelompok yang terhubung ke milenium baru di saat lulus SMA di tahun 2000. Pendapat lain menurut Elwood Carlson dalam bukunya yang berjudul The Lucky Few: Between the Greatest Generation and the Baby Boom (2008), generasi milenial adalah mereka yang lahir dalam rentang tahun 1983 sampai dengan 2001. Jika merujuk pada Generation Theory yang dicetuskan oleh Karl Mannheim pada tahun 1923, generasi milenial adalah generasi yang lahir pada rentang tahun 1980 sampai dengan 2000. Generasi milenial juga disebut sebagai generasi Y. Istilah ini mulai dikenal dan dipakai pada editorial Koran besar Amerika Serikat pada Agustus 1993 (Kemenpppa: 2018).

Penyebutan istilah generasi milenial juga berbeda antar peneliti. Diantaranya pertama ada Tapscott (1998) yang menyebut generasi milenial dengan istilah Digital Generation yang lahir antara tahun 1976-2000. Lalu disusul oleh Zemke et al (2000) yang menyebut generasi milenial dengan istilah Nexters yang lahir pada rentang tahun 1980-1999. Selanjutnya ada Oblinger (2005) menyebut generasi milenial dengan istilah Generasi Y/NetGen, yang lahir antara tahun 19811995. Terakhir ada Howe dan Strauss, Lancaster dan Stillman (2002), serta Martin dan Tulgan (2002) menyebut dengan istilah Generasi milenial/ Generasi Y. Milenial yang dikenal sampai sekarang, meskipun rentang tahun kelahirannya masing-masing berbeda. Seiring berjalannya waktu, generasi Baby Boom mulai menurun, lalu mereka menambahkan generasi $\mathrm{Z}$ yang mulai meramaikan angkatan kerja dalam kelompok generasi. Benesik, Csikos, dan Juhes (2016) mengidentifikasi generasi milenial adalah mereka yang lahir antara tahun 1980-1995 (Kemenpppa: 15).

Sumber lain dari Working With Generations X And Y In Generation Z Period: Management Of Different Generations In Business Life (Sezin Baysal Berkup, Gediz University, İzmir, Turkey, 2014) menyebutkan bahwa generasi milenial atau generasi $\mathrm{Y}$ adalah mereka yang lahir antara tahun 1980 sampai dengan 2001. Pemikiran tersebut sejalan dengan pemikiran Stafford dan Griffis (2008) yang mengemukakan bahwa generasi milenial adalah populasi yang lahir antara tahun 1980 sampai dengan 2000. Terakhir generasi milenial menurut United States Census Bureau (2015) adalah mereka yang lahir antara tahun 1982 sampai dengan 2000.

Generasi milenial juga tidak kalah berkembangnya di Indonesia. Bahkan, beberapa ahli dalam negeri mengemukakan pemikirannya terkait dengan generasi milenial ini. Ada Hasanuddin Ali dan Lilik Purwandi (2017) dalam bukunya Millennial Nusantara menyebutkan bahwa generasi milenial adalah mereka yang lahir antara tahun 1981 sampai dengan tahun 2000. Sementara itu, para peneliti social dalam negeri lainnya menggunakan tahun lahir mulai 1980-an sampai dengan tahun 2000an untuk menentukan siapa saja generasi milenial (Mengenal Generasi Milenial, Sindonews.com, 2018).

Berdasarkan beberapa pendapatdari para ahli dari berbagai negara dan profesi, penentuan siapa generasi milenial dapat ditarik kesimpulan bahwa generasi milenial adalah mereka yang dilahirkan antara tahun 1980 sampai dengan 2000. Selanjutnya konsep generasi milenial Indonesia adalah penduduk Indonesia yang lahir antara tahun 1980-2000. Dengan demikian jika dilihat dari segi usia, mereka 
yang termasuk kedalam generasi milenial ini adalah mereka yang berada dalam rentang usia 19 - 40 tahun, usia muda sampai usia paruh baya atau usia pelajar sampai pekerja.

\section{Interaksi Generasi Milenial Di Media Sosial}

Pengguna internet di dunia menjadi tinggi saat ini salah satunya disebabkan oleh kehadiran generasi milenial. Hal ini disebabkan karena, mereka mampu menguasai berbagai aplikasi, generasi ini juga memiliki lebih dari satu perangkat digital yang menghubungkan mereka dengan internet. Menurut Tapscot (2009) setidaknya ada delapan norma utama para generasi milenial yang berhubungan erat dengan kebutuhan mereka pada internet. Pertama, Kebebasan, generasi milenial adalah generasi yang dikenal suka akan kebebasan. Mereka tidak ingin terikat atau dikekang dan memiliki rasa percaya diri yang tinggi dalam menentukan masa depan. Misalnya saja, kontrak kerja dalam pekerjaan bisa membuat mereka jenuh dan secara berani memilih untuk meninggalkan pekerjaan mereka dan beralih pada pekerjaan yang dapat member mereka kebebasan.

Kedua, Kustomisasi, yang berkaitan dengan personalisasi sebuah produk bagi generasi milenial. Mereka mementingkan personalisasi dan aksesoris meskipun hanya untuk kepentingan estetika saja. Generasi milenial sangat suka dengan sesuatu yang bisa mereka sesuaikan dengan keinginan. Mereka suka memodifikasi berbagai produk untuk dijadikan sebagai citra diri mereka.

Ketiga, Penyelidikan, generasi milenial merupakan generasi yang memiliki kesadaran tinggi terhadap lingkungan. Mereka punya rasa ingin tahu yang besar tentang peristiwa. Mereka menyukai internet karena internet menyediakan berbagai hal yang bisa mereka cari dan kumpulkan serta dijadikan sebagai bahan informasi. Diakui Tapscot (2009) bahwa generasi milenial telah mampu menghasilkan informasi lebih banyak dari pada generasi sebelumnya.

Ke-empat, Integritas, generasi milenial peduli akan nilai integritas seperti kejujuran, keprihatinan, transparan, dan setia kepada komitmen. Mereka juga merupakan generasi yang punya rasa toleransi yang sangat tinggi. Integritas tersebut mereka dapatkan karena internet yang merupakan teman hidup mereka bisa menyediakan berbagai informasi tanpa batas. Mereka bisa menemukan dan menggunakan komunitas-komunitas social seperti Facebook untuk memberitahu semua teman mereka. Kelima, Kolaborasi, generasi milenial adalah kolaborator alami. Generasi milenial berkolaborasi secara online dalam kelompok chat, bermain video game untuk multi user, menggunakan miling list. Mereka saling mempengaruhi melalui yang disebut Tapscot (2009) sebagai N-Fluence network.

Ke-enam, Hiburan, internet memberikan generasi milenial kesempatan yang berlimpah untuk menghibur diri di dunia online. Web menyediakan alat menyenangkan yang dapat dipilih, tempat orang bisa membaca judul-judul berita, mencari sesuatu di Google, memeriksa email, dan berkirim pesan instan dengan orang lain. Bagi generasi milenial, bekerja haruslah menyenangkan dan berharap pekerjaan mampu member kepuasan emosi. Generasi ini bisa berselancar di internet untuk memenuhi kebutuhan ini, atau dalam sebutan Tapscot (2009) bahwa generasi milenial membutuhkan internet dan media social untuk sekedar mendinginkan kepala setelah lelah bekerja.

Ketujuh, Kecepatan, generasi milenial selalu mengutamakan kecepatan. Dalam interaksi di ruang chat misalnya, mereka saling berinteraksi dengan cepat. Pesanpesan yang dikirimkan melalui instan messenger seketika juga akan dibalas. Kedelapan, Inovasi, generasi milenial lahir dalam kultur yang penuh inovasi. Mereka selalu ingin meng-update perangkat digital mereka, sampai rela menabung uang 
belanja sekolah hanya untuk membeli gadget atau game baru. Uniknya, mereka sangat menikmati dan menghargai inovasi yang hadir di tengah mereka. Kehadiran media sosial juga menjadi factor pengaruh tingginya konsumsi internet di kalangan generasi milenial ini. Media social seperti Facebook. Twitter, Instagram, Path, Youtube, Whatsapp, dan lain sebagainya menjadi media bagi generasi milenial untuk menjalin pertemanan serta saling berbagi minat sesame jejaring mereka (Ito et al, 2010). Sistem aktivitas media social menyerupai sistem jaringan, maksudnya setiap individu atau kode saling terhubung dalam bentuk virtual.

Remaja di kawasan Asia Tenggara seperti Malaysia dan Indonesia juga tidak lepas dari aktifitas yang tinggi dalam mengakses media sosial. Sebuah riset yang dilakukan oleh Mustaffa et al (2013) mengkaji ketergantungan terhadap internet dan aktivitas online di kalangan remaja Lembah Kilang, Malaysia menemukan bahwa internet dimanfaatkan oleh remaja untuk berbagi informasi sesame rekan mereka (Fahrimal, 2018: 68). Dalam kajian mereka, Facebook menjadi media sosial paling banyak digunakan oleh responden dalam berhubungan dengan orang lain. Sementara di Indonesia, berdasarkan riset yang dilakukan oleh Qomariyah (2009) terhadap remaja di perkotaan terkait dengan penggunaan internet, didapati bahwa tujuan utama dari para remaja perkotaan mengakses internet didominasi aktivitas mencari kesenangan dan hiburan. Hal tersebut berimbas pada aktifitas yang lebih penting bagi mereka, yaitu, belajar. Selain itu, intensitas mengakses internet yang tinggi bisa membuat remaja terlena dan terjebak dalam realitas virtual yang dihadirkan oleh berbagai program di internet. Di tambah lagi dengan riset yang dilakukan oleh Suparno (2012) juga memperlihatkan keuntungan dari adanya media sosial. Aspek-aspek pemanfaatan dalam situs jejaring sosial di samping digunakan untuk memastikan dari berbagai hal perubahan yang terjadi pada diri remaja, juga digunakan untuk mengekspresikan gejalagejala sosial dan psikologis. Cara ini diwujudkan dengan cara membuat status, mengomentari status atau menyajikan diri agar diketahui orang lain. Sebagai jejaring sosial virtual, individu-individu yang terhubung dalam media social memiliki tipe yang berbeda-beda.

Generasi milenial merupakan generasi yang punya motivasi tinggi, menjunjung kebebasan, lebih kreatif dan inovatif, serta memiliki jiwa enterpreneurship, serta daya kompetitif yang tinggi (Martin, 2005). Prinsip-prinsip inilah yang dipegang teguh oleh generasi milenial. Karakteristik internet yang memberikan kebebasan pada penggunanya memiliki keterkaitan dengan norma yang dipegang oleh generasi milenial. Generasi milenial merupakan generasi yang berbeda dengan generasi sebalumnya, seperti generasi Baby Boomers dan generasi X. Misalnya saja dalam dunia pekerjaan, generasi $\mathrm{Y}$ atau generasi milenial merupakan generasi pemilih. Mereka masuk ke perusahaan yang mereka sukai bukan hanya disesuaikan dengan latar belakang keilmuan, atau harapan akan gaji yang tinggi. Mereka menyeleksi tempat kerja yang bisa member kebebasan untuk berkembang sesuai dengan tuntutan zaman di era digital.

Hal yang tidak kalah pentingnya untuk dipahami adalah generasi milenial memiliki karakter manajemen kerja yang berbeda dengan generasi lainnya. Mereka memiliki cara pandang yang khas dan kemampuan jejaring yang kuat dan luas. Generasi ini cenderung langsung menyampaikan gagasan dan ide secara terang-terangan. Keunikan yang dimiliki generasi milenial ini kadang harus bertentangan dengan ekspektasi dari generasi lainnya (Fahrimal, 2018:70). Generasi milenial terkadang menganggap dunia kerja mereka terlalu birokratis, tidak pro pada ide-ide pembaruan, serta menghambat perkembangan potensi yang mereka miliki. Namun, generasi lainnya 
menganggap generasi milenial terlalu berambisi dan tidak mengetahui strategi dalam mewujudkan ide mereka. Gaya komunikasi adalah hal penting dalam dunia kerja generasi milenial ini. Mereka tidak suka dengan gaya komunikasi bossy dan mereka lebih mementingkan kesetaraan. Manajer yang suka main perintah, sangat tidak disukai oleh generasi milenial. Perintah bukan membentuk kepatuhan bagi mereka, melainkan melahirkan pembangkangan. Generasi milenial membutuhkan teladan dari generasi sebelumnya. Kedepan ini mereka dapat termotivasi untuk terusbelajar. Mempelajari hal baru dalam dunia kerja adalah keinginan hakiki dari generasi milenial.

\section{Penerapan Literasi Media Pada Generasi Milenial Di Era Digital}

Teknologi komunikasi dalam perkembangannya mencakup semua dan semakin lama semakin mengintegrasikan layanan yang membuka kesempatan berinteraksi dari segala penjuru dunia. Jika dulu semua terjadi dengan sederhana, maka sekarang semua terjadi semakin kompleks dengan bantuan teknologi yang semakin cepat. Wolton (2012) mengatakan bahwa dampak yang muncul dari telepon memang berbeda dari yang dimunculkan oleh radio dan televisi, serta beberapa pula dari segala hal yang timbul akibat komputer. Berbagai terminal yang berbeda-beda mengacu pada kultur yang berbeda-beda pula. Sebaliknya kelak di kemudian hari, segalanya akan tersedia di terminal semacam itu pula. Perubahannya bukan hanya bersifat teknik, namun juga cultural karena kita tidak akan melihat lagi perbedaan antara berbagai aktivitas sebelumnya yang terpisah-pisah selama berabad-abad.

Di tengah banyaknya manfaat yang diberikan oleh internet kepada peradaban manusia, namun aspek etis selalu menjadi permasalahnya. Di satu sisi, internet membuka jalan bagi terciptanya hubungan baru serta jaringan tidak langsung antarin dividu yang menyatu dan lebih mengikat (Slevin dikutip McQuail, 2011). Di sisi lain, internet dan sifat penggunaannya mengarah pada menciptakan perpecahan sosial (Fahrimal, 2018: 70). Internet mengubah secara radikal cara manusia berkomunikasi dan berpikir. Dalam pemahaman Carr (2010) internet telah mendangkalkan cara berpikir manusia. Kecepatan yang dihadirkan internet justru membuat kita semakin mencintai sesuatu yang instan, malas untuk bergerak, dan merasa banyak tahu.

Populernya media sosial di kalangan generasi milenial, telah meningkatkan resistensi dalam dunia nyata. Media social digunakan oleh generasi milenial untuk mengekspresikan eksistensi mereka. Dalam konstruksi pikiran mereka, sehari saja tidak mengakses media social seperti tercabut dari peradaban (Fahrimal, 2018: 71). Eksistensi ini ditunjukkan melalui mengunggah gambar, video, komentar, ucapan, kata-kata penghiburan, kutipan inspirasional dan gambar yang diambil dari situs web seperti Photobucket di profil mereka (Martinez 2010). Kebanyakan di antara mereka melakukan stalking kesetiap akun yang menarik perhatian mereka. Beberapa pengguna media social bahkan mencaritahu informasi tentang teman mereka meskipun mereka sudah tidak bicara untuk waktu yang lama (Gershon, 2010).

Berdasarkan informasi yang didapat dari laman dreamgrow.com, terdapa tempat media sosial yang paling populer dan banyak digunakan oleh generasi milenial di tahun 2017, yaitu, (1) Facebook, pengguna media sosial yang dibangun oleh Mark Zuckerberg ini melonjak sebesar 60 juta pengguna aktif bulanan dari 1,94 milyar pada maret 2017 menjadi 2,00 milyar pada Juni 2017. Tingkat pertumbuhan tampaknya berlanjut pada 20 juta pengguna aktif per bulan; (2) Youtube; (3) Instagram; dan (4) Twitter. Menurut laporan smartinsights.com (2017) para pengguna media social ini didominasi 
oleh mereka yang berada dalam rentang usia 18-34 tahun (Fahrimal, 2018: 71).

Situs media sosial sering kali disalahkan karena menyebabkan kecanduan remaja dan mengisolasi remaja dari teman sebaya dan keluarganya. Dengan demikian, teknologi digital baru telah menjadikan situs pertentangan utama -melibatkan orang tua, guru, media dan negara - tentang bagaimana penggunaan teknologi digital oleh kaum muda arus diatur (Fahrimal, 2018:71). Oleh karenanya, kecanduan tersebut telah membawa konsekuensi pelanggaran etika dan moral di media sosial. Kondisi tidak ada etika dalam ruang virtual ini dikarenakan euphoria manusia dalam menyambut teknologi media baru.

Media sosial menjadi ruang tempat generasi milenial menarik dirinya dari dunia nyata, menarik diri dari tubuhnya, menarik diri dari kenyataan dan problem sosial untuk kemudian masuk kedalam dunia yang bersifat halusinasi. Dalam ruang itu peran, ego, dan identitas dibangun dalam wujud artifisial dan virtual. Secara kritis Piliang (2011) menyebutkan disini sebagai disorder, yaitu, era dimana kegilaan manusia atas pemujaan berlebihan kepada ruang virtual. Di dalam ruang virtual terjadi pengingkaran akan setiap batas, hambatan, aturan, dan ideology sebagai perekat atau gravitasi sosial. Oleh karena itu, manusia dapat mengembara secara bebas di dalam dunia fantasi, halusinasi, dan ilusinya tanpa perlu ada pengendalian sosial, moral, spiritual, dan etika. Jika demikian, maka tidaklah heran jika media social sangat dekat dengan hal-hal yang berkaitan dengan pelanggaran etika, moral, dan nilai-nilai spiritual yang sifatnya universal.

Pengguna internet dan media social adalah manusia, maka seluruh transaksi informasi yang terjadi di media social tidak dapat dipisahkan dari aspek etika. Etika di ruang siber berbeda dengan bentuk etika lainnya dan perlu mendapat kajian khusus karena proses komunikasi yang terjadi menggunakan teknologi untuk berkomunikasi. Ini merupakan sebuah fenomena baru yang tidak selalu dipahami dengan baik karena institusi utama pendidikan etika (sekolah, institusi agama, dan keluarga) belum mengajarkan sepenuhnya etika dalam dunia siber yang termediasi computer ini (Vesna dan Niveditha, 2012). Sama seperti aturan etika di dunia nyata, dunia siber juga mendorong para pengguna untuk taat pada aturan etis dan moral untuk menciptakan ruang bersama yang nyaman, tentram, dan damai. Tetapi, aturan itu terkadang sengaja diabaikan khususnya oleh generasi milenial. Mereka merasa ingin bebas dan menjadikan ruang siber sebagai ruang privasi.

Pelanggaran etika di dunia siber berupa penyebaran informasi palsu, transaksi ilegal, penipuan, penyedotan data, cyber bullying, pronografi, human trafficking, ujaran kebencian, dan lain sebagainya (Monggilo, 2016). Berdasarkan hasil riset Andina (2010) mengungkapkan jika Facebook sebagai salah satu media sosial yang paling banyak digunakan oleh generasi milenial dan menjadi aplikasi paling berdampak negatif terhadap mereka. Transaksi informasi di Facebook menyebabkan konflik karena perbedaan pendapat, prostitusi dan perjudian online, serta meningkatnya penipuan dan penculikan. Hasil penelitian Whittaker dan Kowalski (2015) mendapatkan bahwa tren cyberbullying sangat tinggi di media sosial. Pelaku didominasi oleh remaja yang sering menyerang teman sebaya mereka dalam ruang komentar (Fahrimal, 2018: 73). Kedua riset ini menunjukkan pada kita bahwa generasi milenial sangat mudah melakukan pelanggaran etika siber yang bisa berbahaya bagi perkembangan mental baik individu maupun sosial.

Generasi milenial lahir dan berkembang dalam kepungan teknologi. Generasi ini mungkin tidak sadar akan pentingnya etika dalam ber-media sosial (Tedre, 2006; Vesna dan Niveditha, 2012). Internet sebagai kendaraan media social memiliki kecepatan dalam menyebarkan 
informasi kepada seluruh orang yang terkoneksi. Sehingga apa yang kita unggah ke akun media sosial, bukan hanya orangorang dalam jaringan kita yang akan melihat namun dapat di-share oleh teman kita sehingga dapat dilihat oleh orang lain yang tidak berteman dengan kita namun menjadi jaringan komunikasi teman kita.

Generasi milenial, sebagai manusia yang hidup dalam kepungan teknologi ternyata memiliki sisi lemah. Sama dengan produk teknologi yang sering digunakannya, generasi milenial mempunyai sisi negatif yang membuat mereka tidak lepas dari kritik tajam. Aspek yang paling menonjol dari generasi milenial adalah etika dan moral yang mereka tampilkan di ruang publik secara virtual. Untuk adat timur seperti Indonesia, etika dan moral merupakan hal yang sangat penting. Pelanggaran terhadap etika dan moral sosial berarti mengingkari system sosial yang ada dengan norma kebebasan yang dibawa oleh generasi milenial (Tapscot, 2009), mereka sering abai terhadap etika dan moral dalam kehidupan bermasyarakat. Hal-hal tidak etis seperti, ujaran kebencian, bullying, akses konten pronografi, menyebar berita palsu (hoax), judi online, penipuan, dan lain sebagainya sering dilakukan saat berselancar di internet. Karakteristik lain yang mungkin juga dilupakan generasi milenial adalah setiap postingan di media social itu terdokumentasikan dengan baik secara sengaja atau pun tidak.

\section{PENUTUP}

\section{Kesimpulan}

Kehadiran generasi milenial di era digital saat ini memberikan pengaruh yang sangat signifikan dalam perkembangan literasi media. Generasi milenial juga banyak memberikan sumbangsih dalam maraknya penggunaan media sosial di dunia siber. Hanya saja, masih banyak kekurangan yang dirasakan setiap berselancar di media sosial, diantaranya adalah informasi yang masih minim sentuhan literasi media yang ada di media sosial. Penelitian ini dilakukan untuk meninjau bagaimana perkembangan literasi media pada generasi milenial di era digital, dan didapatkan kesimpulan sebagai berikut:

1. Literasi media di era digital masih belum diterapkan dengan baik dalam masyarakat meskipun mereka sudah mahir menggunakan perangkat digital. Hal ini bisa dilihat masih banyak ditemui informasi yang belum jelas kebenarannya tersebar di media sosial oleh masyarakat.

2. Generasi milenial adalah sebutan untuk generasi yang lahir dalam rentang tahun 1980 sampai tahun 2000. Mereka yang dikatakan generasi milenial adalah generasi yang saat ini berusia mulaidari 19 tahun sampai 40 tahun, atau usia sekolah sampai usia produktif/pekerja.

3. Interaksi generasi milenial dengan media sosial di era digital sangat intens. Generasi ini sangat suka berselancar di media social untuk berbagi informasi, hiburan, menonjolkan eksistensi diri, bergaul dengan komunitas dalam grup chat.

4. Perkembangan literasi media pada generasi milenial di era digital ini masih belum sesuai harapan. Generasi milenial belum mendapatkan pengetahuan yang baik mengenai literasi media, sehingga masih banyak ditemui pelanggaran dalam bermedia sosial khususnya dalam hal menyaring dan menyebarkan informasi kepada publik.

\section{Saran}

Melihat gencarnya generasi milenial menggunakan media sosial di era digital ini, perlu mendapat pemahaman yang baik mengenai literasi media. Adapun beberapa saran yang perlu mendapat perhatian terkait dengan literasi media di era digital oleh generasi milenial adalah sebagai berikut:

1. Masyarakat perlu mendapatkan pemahaman yang baik mengenai literasi media khususnya generasi milenial di 
media sosial, supaya mereka tidak terjebak dalam penyebaran informasi yang belum jelas kebenarannya atau informasi yang mengandung berita palsu dan unsure provokatif.

2. Pemerintah perlu meninjau atau merancang kebijakan yang mengatur penyebaran informasi public menjadi lebih baik dan tidak ada pelanggaran lagi, melalui undang-undang atau lembaga penyiaran.

\section{DAFTAR PUSTAKA}

Ainiyah, Nur. 2018. Remaja Millenial Dan Media Sosial: Media Sosial Sebagai Media Informasi Pendidikan Bagi Remaja Millenial. Volume 2 No. 2. JPII.

Ali, H., dan Lilik Purwandi. 2017. Millennial Nusantara Pahami Karakternya, Rebut Simpatinya. Jakarta, PT Gramedia Pustaka Utama.

Baran, Stanley J. 2011. Pengantar Komunikasi Massa: Literasi Media dan Budaya. Jakarta, Salemba Humanika.

Carr, N., 2010. The Shallows: Internet Mendangkalkan Cara Berpikir Kita?.. Bandung, Mizan.

Choirul, Afif. 2013. Tingkat Literasi Media Berbasis Kompetensi Individual Mahasiswa Fakultas Dakwah dan Ilmu Komunikasi IAIN Sunan Ampel Surabaya. Prosiding.
Fahrimal, Yuhdi. 2018. Netiquette: Etika Jejaring Sosial Generasi Milenial Dalam Media Sosial. Jurnal Penelitian Pers dan Komunikasi Pembangunan Vol. 22 No.1.

Fitryarini. Inda. 2016. Literasi Media Pada Mahasiswa Prodi Ilmu Komunikasi Universitas Mulawarman. Jurnal Komunikasi Volume 8 No.1.

Iriantara, Yosal. 2009. Literasi Media: Apa, Mengapa, Bagaimana. Bandung: Simbiosa,Rekatama Media.

Ito, M., et al., 2010. Hanging Out, Messing Around, and Geeking Out: Kids Living and Learning with New Media. Cambridge, MA: MIT Press.

Jefkins, Henry. 2009. Confronting The Challenges of Participatory Culture: Media Education for The 21st Century. Illinois: MacArthur Foundation.

Kementrian Pemberdayaan Perempuan dan Perlindungan Anak. 2018. Profil Generasi Milenial Indonesia. Jakarta, Kementerian Pemberdayaan Perempuan dan Perlindungan Anak.

\section{Sumber Internet :}

Koran Sindo. (2018, Januari 18). Generasi Milenial dan Pudarnya Nasionalisme Pangan. Dipetik September 12, 2018, dari Sindonews.com:

https://nasional.sindonews.com/read/1274

556/18/generasimilenial-dan-pudarnyanasionalisme-pangan-1516213536/13 